The University of Akron

\title{
IdeaExchange@UAkron
}

June 2016

\section{Jungles, Rabbit Holes, and Wonderlands: Comparing conceptions of museality and document}

Kiersten F. Latham

Kent State University, kflatham@kent.edu

Please take a moment to share how this work helps you through this survey. Your feedback will be important as we plan further development of our repository.

Follow this and additional works at: https://ideaexchange.uakron.edu/docam

Part of the Library and Information Science Commons

\section{Recommended Citation}

Latham, Kiersten F. (2016) "Jungles, Rabbit Holes, and Wonderlands: Comparing conceptions of museality and document," Proceedings from the Document Academy: Vol. 3 : Iss. 1 , Article 9.

DOI: https://doi.org/10.35492/docam/3/1/9

Available at: https://ideaexchange.uakron.edu/docam/vol3/iss1/9

This Article is brought to you for free and open access by University of Akron Press Managed at IdeaExchange@UAkron, the institutional repository of The University of Akron in Akron, Ohio, USA. It has been accepted for inclusion in Proceedings from the Document Academy by an authorized administrator of

IdeaExchange@UAkron.For more information, please contact mjon@uakron.edu, uapress@uakron.edu. 


\section{Introduction}

I am writing this brief piece about a concept called museality in the context of neodocumentation studies and concepts. This follows from my presentation at the 2012 Document Academy (DOCAM) conference, titled "Exploring the Museal Jungle," and a subsequent exhibition, called "Museality" (2014) at Kent State University MuseLab two years later. Coming from the field of museum studies, but working also in library and information science (LIS), it became clear to me that foundational concepts in document studies and in museum studies were conceptually similar. The presentation in 2012 was my way of working out the relationship between the terms surrounding document and museality to determine whether the terms were correspondingly identical. I am committing a portion of that talk to 'paper' here in the interest of furthering the conversation around document studies and museum studies between all regions of the world that practice and theorize in both areas.

I believe that museum studies and document studies can mutually benefit from each other, warranting such an investigation. This article will serve, then, as an initial mechanism for the exploration into the history, use, and comparative usefulness of museality and document in museum studies, in order to blaze a path towards organizing their relationship and potential use in practice. This paper will provide no solutions and will come to no final conclusions; this exploration is purposefully open-ended and ongoing, and encourages feedback and suggestions. In fact, its purpose is similar to the DOCAM 2012 presentation, to spark conversation about these two fields, their concepts, and objects of study.

While there have been those who have explored the notions of document and museality in the past (especially in certain portions of Europe), this blend is not common in the U.S. where I work and teach. Just as the neo-documentation movement is foreign to U.S. museum studies (and perhaps many U.S. LIS) programs, the concept of museal is just as unfamiliar. Both concepts offer the field of museum studies a new approach to understanding the nature of museum work, the experiences of museum users, and the role of museums in society. There are unexcavated relationships between these concepts that deserve a direct exploration to uncover any prospective synergies. In my work as a museologist, I have found great potential capacity in document studies. In my opinion, it is beneficial to bring these two fields inato the same conversation with each other. Below, I offer a first, tentative step.

\section{The Museal Jungle: Museal, Musealia, Museality, Musealization}

The museal jungle is very tangled and dense. It involves many countries (and languages), several time-periods, politics, academic territories, regime changes, an 
ocean or two, and many unpublished documents. But just as a real jungle, there is great potential here. Mysteries and potential discoveries loom on the horizon.

In the 1970s, the European museology community began to develop the new science of museum studies (Desvallées \& Mairesse, 2010). Among the concepts that were articulated during this period were the terms museal, musealia, musealization, and museality. This terminology has yet to take hold in the U.S. ' but has become essential to European and Latin American museum studies literature. The concept of musealia was developed by Czech museologist, Zbyněk Stránský in the 1960s and 1970s during a series of meetings in Eastern Europe and Germany about the purpose of museums (Desvallées \& Mairesse, 2010).

In 2010, ICOFOMii published (from work beginning in 1993) the Encyclopedic Dictionary on Museology (Desvallées \& Mairesse, 2010) that defines the various terms around museality (in my courses, we call these the "M words").

Museal: a specific relationship with reality; on level with "political," "social," "religious," "economic"; museums did not bring about museology but rather museology (museality) brought about museums (i.e. it goes beyond museums)

Musealization: the operation for extracting a thing, physically or conceptually, from its original, natural, or cultural environment and providing it with museal status (turning it into a museum object, or musealium); placing it into the museum field

Musealia: things that have experienced the process of musealization; objects are not in themselves a reality but instead outputs, results, correlations; made to be shown (to move emotions, distract, or instruct); the object is always what the subject places before him/her as different from him/herself

This publication was team-developed, by mostly French-speaking authors. It includes the essential notions of museology and a dictionary of museologyrelated terms. The concept of museal, and its related terms-musealia, musealization, museality-has since become integrated into the European and Latin-American museum studies literature since its introduction in the 1960s. Referring to a "specific relation to reality" (Desvallées \& Mairesse, 2010, p.49), the concept of museality has been used as a theoretical field of reference meant to provoke thinking about objects of culture. The concept is useful in understanding the role of museum objects, the meaning of collecting, and human experience with 
things. As mentioned above, museality as a concept has not taken hold in most U.S. museum studies programs, and especially not in museum practice, but in actuality, the concept can be extremely useful in practice. This understanding can help museum professionals make intentional and reflective decisions about what to collect, care for, exhibit, and research. Even more, museal things are not necessarily only found in museums; museal can refer to things outside of a museum that have been musealized, such as monuments, sites, buildings, even cities. In other words, the value of this concept goes beyond the doors of the museum as an institution.

There are many Eurpean museologists who discuss the role and meaning of museality. Much of this literature is not in English, making access for many Englishonly speakers in the U.S. difficult. Of particular importance to this topic was Croatian museologist, Ivo Maroević, a philosopher and theorist about all things museal. A few of his publications were translated into English, such as Introduction to Museology: The European Approach (translated in 1998) where he attempted to help the reader understand this tricky concept a bit more. He described museality as:

- the characteristic features inherent in the object itself or attributed to it

- the parts of reality recognized only in the representation of some aspect of the cultural or natural world

- the focal point of concern is the documentary value of the object

- the work of the museum

Museology, Maroević said,

"is the function of the relation between musealia and the knowledge that can be gained by recording or signifying the contents (meanings), while musealia is a function of the relation between material, form and museality in the elements of the material world" (Maroević, 1998, p. 138).

In this book, Maroević (1998) outlined his concept of the the museal field, a communication process, and its relationship between museal definiteness and museal indefiniteness as a function of musealization. Defining the museum content of musealia, he said, is a communication process whereby "the field of 'museal indefiniteness' of such a document of reality is constantly decreasing" (p. 135). 


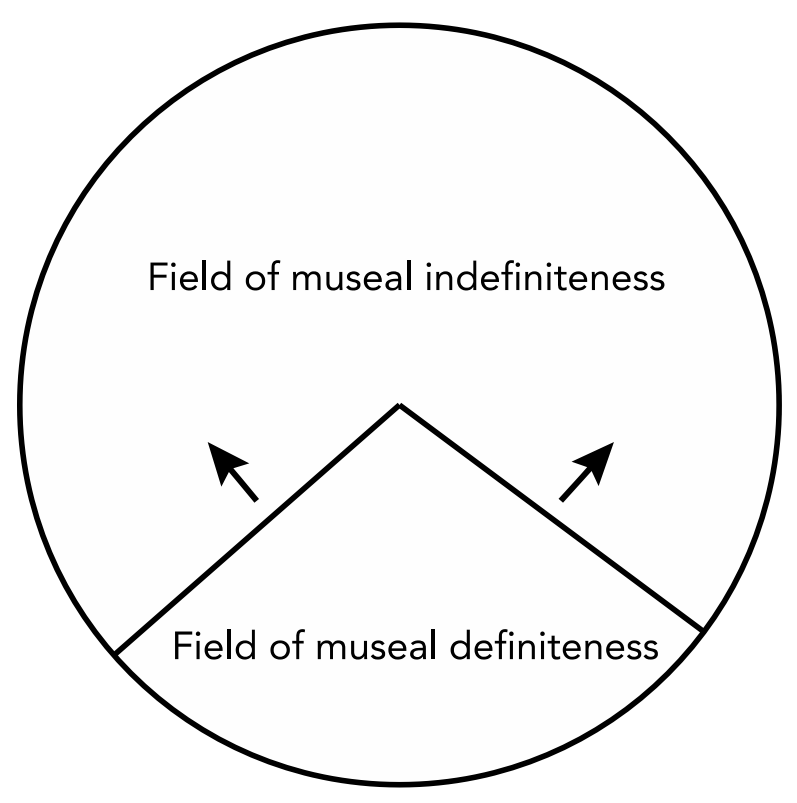

Figure 1. Adaptation of Maroevićs museal field, showing the relationship between museal definiteness and museal indefiniteness.

Here we see that the museum object (musealia) is a result of a communication process (musealization) whereby the field of museal definitiness increases as the object is processed into the museum. When the object enters the museum, it now has a role to communicate information to those who witness it. Maroević was focused on the relationship between the curator and the object as the point where museal indefiniteness decreased. Today, however, we could adapt this model to talk about the communication between all users-including museum visitors-and the object.

Quite a lot can be said about the European literature surrounding the museality concept. There are more models that could be compared and discussed (eg. Težak's E-T-Ac-S-A complex, Tudjman's IN-DOC system, and more). However tempting it may be to introduce more models of museality, the point of this paper is to explore any relationships between museality and document. For that reason, 
I will let what has been presented thus far serve as an introduction and we will move into the next section to compare the terms.

\section{Monkeying around with Branches in the Jungle}

Below is an admittedly highly simplified presentation of a tangle of complicated material in an initial attempt to sort this out. I will first look at the origins and central thinkers around the development of the two terms. Next I provide a comparison of single definitions of document in the neo-documentation tradition and compare them to the definition for museality.

\section{Foundations: Origins \& Thinkers}

The recent (re)development of document over the past couple of decades seems to parallel the development of the museality concept, and in similar places. Table 1 shows a general comparison of the two concepts regarding their origins and central proponents (thinkers). Both concepts emerged in the late $20^{\text {th }}$ century and both in Europe, but each developed in different scholarly circles, for the most part. What is most striking here is that, with the exception of Stránskýiii (1994) who drew out Otlet and the idea of "documentation" in relation to museality, the central thinkers of these concepts have no overlap. Granted, I have not yet researched the historical and evolutionary contexts around these areas in great depth so my presentation of this table is to be considered preliminary.

Table 1. General comparison of the origins and thinkers of document (in neodocumentation tradition) and museality.

\begin{tabular}{|l|l|l|}
\hline \multirow{5}{*}{ Origins } & Document & Museality \\
\cline { 2 - 3 } & Developed in bibliographic (library) circles & $\begin{array}{l}\text { Developed in museological (museum \& } \\
\text { heritage) circles }\end{array}$ \\
\cline { 2 - 3 } & $\begin{array}{l}\text { Emerged (or re-emerged in present form) in } \\
\text { late 20thc }\end{array}$ & Emerged in late 20thc \\
\cline { 2 - 3 } & $\begin{array}{l}\text { Developed in Europe } \\
\text { Contextual, environmental, epistemological } \\
\text { Thinkers }\end{array}$ & $\begin{array}{l}\text { Developed in Europe } \\
\text { Contextual, environmental, epistemological } \\
\text { similarities }\end{array}$ \\
\hline \multirow{2}{*}{$\begin{array}{l}\text { Suzanne Briet (French) } \\
\text { Michael Buckland (British/American) }\end{array}$} & $\begin{array}{l}\text { Ivo Maroević (Croatian) } \\
\text { Jiri' Neustupny' (Czech) } \\
\text { Ron Day (American) } \\
\text { Bernd Frohmann (Canadian) } \\
\text { Niels Lund (Danish/Norwegian) }\end{array}$ & $\begin{array}{l}\text { Zbynek Stránský (Czech) } \\
\text { Lynn Teather (Canadian) } \\
\text { Peter van Mensch (Dutch) }\end{array}$ \\
\hline
\end{tabular}

Document, Document, Musealia! 
Are musealia documents or are documents musealia (or both or neither)? The list of definitions found below in Table 2 is not exhaustive but was gathered from authors who directly define documents and documentation within the neodocumentation tradition. Further exploration of the works from others who influence both museology and document studies such as Benjamin, Foucault, Latour, etc, are needed in the future. For now, I will keep our focus only on document theorists for the sake of early exploration.

Table 2. Comparing the definition of musealia with definitions of document from document theorists.

\begin{tabular}{|c|c|}
\hline Musealia & $\begin{array}{l}\text { Things that have experienced the process of musealization; a specific } \\
\text { relationship with reality through change of context and } \\
\text { accumulation/presentation }\end{array}$ \\
\hline Author & Definition of document (in neo-doc tradition) \\
\hline Briet (2006) & $\begin{array}{l}\text { Any concrete or symbolic indexical sign [indice], preserved or recorded } \\
\text { toward the ends of representing, of reconstituting, or of proving a } \\
\text { physical or intellectual phenomenon; proof in support of a fact }\end{array}$ \\
\hline Buckland (1991) & Any signifying thing; any expression of human thought \\
\hline Day (2014) & $\begin{array}{l}\text { Any type of ontological substance that acts as evidence; or, something } \\
\text { that points to something else }\end{array}$ \\
\hline $\begin{array}{l}\text { French Union of } \\
\text { Documentation } \\
\text { Organizations (1935 } \\
\text { in Lund \& Skare, } \\
\text { 2009) }\end{array}$ & $\begin{array}{l}\text { All bases of materially fixed knowledge, and capable of being used for } \\
\text { consultation, study and proof }\end{array}$ \\
\hline Frohmann (2004) & $\begin{array}{l}\text { Different material kinds of temporally spatially situated bundles of } \\
\text { inscriptions embedded in specific kinds of cultural practices } \\
\text { (questionable need for definition; depends on application, context) }\end{array}$ \\
\hline $\begin{array}{l}\text { Int'l Inst. for } \\
\text { Intellectual } \\
\text { Cooperation (1937 in } \\
\text { Buckland, 1997) }\end{array}$ & $\begin{array}{l}\text { Any source of information, in material form, capable of being used for } \\
\text { reference or study or as an authority }\end{array}$ \\
\hline Levy (2001) & $\begin{array}{l}\text { Talking things (bits of material world we have imbued with ability to } \\
\text { speak) }\end{array}$ \\
\hline Lund (2004) & $\begin{array}{l}\text { Any results of human efforts to tell, instruct, demonstrate, teach or } \\
\text { produce a play, in short to document, by using some means in some } \\
\text { ways. }\end{array}$ \\
\hline
\end{tabular}

When compared to the definition of musealia-things that have experienced the process of musealization; a specific relationship with reality through change of context and accumulation/presentation-this list of definitions reveals similarities around the relationship with reality, contextual change, acting as a communicator, and materiality. 
The "specific relationship with reality" that is the core of museality is present in many definitions of document-as an index, symbol, representation, signifier, referent-showing that both document and musealia act as representations, indices, or signifiers. On this point, the definitions appear to be referring to the same meaning. A musealized object enters a "new reality," that is, it is extracted from original environment and placed into museal field (another reality). Stránský (1970, in Desvallées \& Mairesse, 2010) noted that an object that lives in the reality of the museum is to be considered a document of the reality from which it has been taken. Maroević (1998) noted that we should not forget that the museum object contains and transmits information and documents through different forms of reality through which it has passed.

In the same vein, both document and musealia require some change of context, some shift to become evidence, proof, or representation. Musealia are transformed into material evidence of mankind and environment through a change in context and a selection process, and are both intended to be experienced and understood. Musealia are a part of a symbolic order (index), which grants them new meaning and value.

Another commonality is that the document (musealia) acts as a communicator, or potential communicator. While this is not explicitly in the musealia definition, other discussions in the literature about it reveal that communication is a major factor (eg. Maroević, 1998, van Mensch, 1992). The document definitions include forms of communication: a source of information, talking things, demonstrative, instructive, expression of thought, reconstituting. All of these can be applied to the notion of museality and musealia.

Materiality is currently a hot point of discussion (eg. DeMarrais et al, 2004; Frohmann, 2007; Dudley, 2010; Joyce, 2015) in both the museum studies literature as well as in the document studies literature. It is probably no surprise that materiality can be found in both definitions of document and musealia and remains a central characteristic for both. The purpose of musealia are to act as devices to explore and experience reality by means of sensitive perception; they are "made to be shown" (Desvallées \& Mairesse, 2010). How each field defines materiality, however, may be a different discussion between the two and warrants further inquiry.

This brief comparison of definitions reveals clearly that a deeper investigation of both concepts is needed to explore the many ramifications of the two terms. In my DOCAM 2012 talk, I dug in with a slightly deeper comparison between a selection of document theorists' conceptions of document with museality-Briet, Buckland, Lund, and Frohmann with Maroević, Stránský, and van 
Mensch. Such an investigation is reserved for a subsequent article on this topic as it cannot be quickly presented here.

\section{So What? Rabbit Holes and Wonderlands}

Any paper worth writing should pass the "so what" test. Where does this get us? There is clearly a close relationship between the terms document and museality (in all its forms). What are the implications of this, if true? Further and deeper investigation comparing concepts from each side could include:

- Agency of documents/musealia

- Documentality-the same as museality?

- Compare methods of analysis

- Investigation of object vs. material culture (yet another field!) vs. document

- Document genres and museal concepts

- Document practices and museal concepts

- Historical development of each

- What does production \& reproduction mean in both?

If we link the terms, we can ferret out the gaps in each and use work from both fields to apply to the other, a mutually beneficial exercise. Perhaps this effort can serve as a bridge between the fields, helping them to speak to each other in a similar language, thereby spurring greater understanding of the human relationship with things. Is this investigation and potential bridging of two fields at their foundations worthwhile? Take a look at some of the most pressing problems for museums. We are still grappling with these basic questions, and aligning these two fields could help us to address them:

- What is a museum?

- What is a collection? Ideas or Objects?

- Whose museum is it? Who owns the museum?

As promised, this paper did not deliver a solution or outcome. That, after all, is what an open-ended exploration is all about. When I presented this material to DOCAM 2012 I asked the attendees:

Do you see a point in this exploration? How could it ultimately be useful? Where could it go? 
And...Does it matter?

Or, does the fact that musealia seems similar to document just show that document as a concept works?

I am still interested in receiving feedback on this exploration. Is this a rabbit hole best left to the rabbits? Or is it a Wonderland worth pursuing? I end this beginning with a statement that resonated with me about this exploration, from document theorist, Bernd Frohmann (2008):

The benefits of extending the concepts of document and documentation are located here, and with a closely associated aim, that of multiplying these concepts and seeking ways of also extending an encouraging hospitality to many different areas of their application (p. 301).

My interpretation: Let's go down the rabbit hole. 


\section{References}

Day, R. E. (2014). Indexing it all: The subject in the age of documentation, information, and data. Cambridge, Massachusetts: The Mit Press.

Desvallées, A. \& Mairesse. F. (2010). Key concepts of museology. International Council Of Museums, Armand Colin.

Lund,N.W. \& Skare, R. Document Theory. In Encyclopedia of Library and Information Sciences, Third Edition. Taylor and Francis: New York, Published online: 09 Dec 2009; 1632-1639.

Lund, N.W. (2004), "Documentation in a complementary perspective", papers of the 2001 Nordic-International Colloquium on Social and Cultural Awareness and Responsibility in Library, Information, and Documentation Science (SCARLID), Scarecrow Press, Lanham, MD.

Buckland, M. K. (1991). Information as Thing. Journal of the American Society for Information Science, 42, 5, 351-60.

Buckland, M. (1997). What is a "document"? Journal of the American Society for Information Science, 48, 9, 804-809.

Briet, S. (2006), What is Documentation? English Translation of the Classic French Text (trans. By Day, R.E. and Martinet, L.), The Scarecrow Press, Lanham, MD.

DeMarrais, E., Gosden, C., Renfrew, C., \& McDonald Institute for Archaeological Research. (2004). Rethinking materiality: the engagement of mind with the material world. Cambridge; Oakville, CT: McDonald Institute for Archaeological Research; Distributed by Oxbow Books, David Brown Book Co.

Dudley, S. H. (Ed.). (2010). Museum materialities: Objects, engagements, interpretations. London; New York: Routledge. Retrieved from http://www.worldcat.org/title/museum-materialities-objectsengagements-interpretations/oclc/308216483\&referer=brief_results 
Frohmann, B. (2004). Documentation Redux: Prolegomenon to (Another) Philosophy of Information. Library Trends, 52, 387-407.

Frohmann, B. (2007). Multiplicity, materiality, and autonomous agency of documentation. In R. Skare, N. W. Lund, \& A. Va ${ }^{\circ}$ rheim (Eds.), A document (re)turn: contributions from a research field in transition. Frankfurt am Main; New York: Peter Lang.

Frohmann, B. (2008). Revisiting "what is a document?." Journal of Documentation, 65, 2, 291-303.

Gorichinaz \& Latham (upcoming 2016). Document phenomenology: A framework for holistic document analysis. Journal of Documentation.

Joyce, R. (2015) History and Materiality. In, Emerging Trends in the Social and Behavioral Sciences, R. Scott and S. Kosslyn (eds). John Wiley \& Sons, Inc.

Levy, D. M. (2001). Scrolling forward: Making sense of documents in the digital age. New York: Arcade.

Maroević, I. (1998). Introduction to museology: The European approach. Munich: C. Müller Straten.

Stránský, Z. (1994). Object-document, or do we know what we are actually collecting? In, OBJECT - DOCUMENT? Symposium, Beijing, China, M. Schärer (ed). ICOFOM Study Series, ISS23.

Van Mensch, P. (1992). Towards a Methodology of Museology. Ph.D. diss., Univeristy of Zagreb. 


\begin{abstract}
i For a variety of reasons that are not clearly articulated, using the conceptual and theoretical tool of museality has not taken hold in U.S. museums or museum studies programs. Language could be one issue and the fact that most programs in the U.S. have been oriented practically rather than theoretically is another. ii International Committee for Museology, a committee of the larger International Council of Museums (ICOM).

iii Stransky, ironically, was not interested in sharing between fields but wanted to keep "material sources" in "our domain."
\end{abstract}

